\title{
Is a Strategy Focused on Super-Utilizers Equal to the Task of Health Care System Transformation? Yes.
}

\author{
Uchenna Emeche, MD \\ Franklin Square Medical Center, Baltimore, Maryland \\ Ann Fam Med 2015;13:6-7. doi: 10.1370/afm.1746.
}

$\mathrm{T}$ The super-utilizer (SU) strategy is pivotal to health care system transformation. ${ }^{1}$ Super-utilizers are patients with high medical costs from recurring, preventable inpatient or emergency department (ED) visits. ${ }^{2}$ Although super-utilizers represent $5 \%$ of the population, they account for $50 \%$ of health care expenditures. ${ }^{3}$ The SU strategy focuses on reducing these expenditures by reducing preventable hospital visits, employing a strategy based on data, ${ }_{1}^{6}$ stakeholder engagement, and clinical redesign. It is clear that system transformation requires fundamental changes to produce high value care or improved outcomes at lower cost. ${ }^{4}$

The SU strategy was developed when Dr Jeffrey Brenner translated law enforcement hotspot concepts to medicine, identifying and then allocating resources to outliers of hospital utilization in the same way police departments identify and staff high crime areas. ${ }^{5}$

Community-based care coordination is a home-visit program that connects super-utilizers with primary care and community resources, and is the crux of SU clinical redesign. ${ }^{2}$ Care coordinators (licensed practical nurse, medical assistant, or social worker) work with super-utilizers to abate social determinants that contribute to high utilization and expenditures (ie, lack of transportation, lower education, housing insecurity).

Program administrators (registered nurse and program manager) and health coaches comprise the multidisciplinary care coordination team. The team is supported by a dynamic data infrastructure that identifies super-utilizers, tracks utilization and spend-

Conflicts of interest: author reports none.

\section{CORRESPONDING AUTHOR}

Uchenna Emeche, MD

Franklin Square Hospital

9101 Franklin Square Drive

Medical Arts Bldg, Ste 205

Baltimore, MD 21237

uchennaemeche@gmail.com ing trends, reports outcomes, and supports continuous process improvement. The strategy aligns patients' needs and community assets through stakeholder engagement, creating partnerships between patients, teams, payers, community, and health care resources. ${ }^{7}$ In Camden, New Jersey, a study is underway to evaluate this model's outcomes and potential cost savings.

One doesn't have to wait for results of the Camden study to find data supporting key elements of the SU strategy. A nurse-led care coordination program in Doylestown, Pennsylvania has demonstrated improved outcomes and lower expenditures among Medicare beneficiaries for over 10 years. ${ }^{8}$ This randomized control trial demonstrated a $25 \%$ lower mortality risk, and in the highest risk population-defined as $\geq 1$ admission in the past year along with a diagnosis of heart failure, coronary disease, or COPD—a $36 \%$ reduction in Part A and B Medicare expenditures. ${ }^{8,9}$

The early success of these and other emerging programs is guiding policy. An SU learning collaborative not only developed key policy recommendations, but is working at the state level to advocate for reform. ${ }^{10}$ Combined data from 3 of the programs demonstrated a $34 \%$ reduction in hospital admissions and savings of $\$ 1.2$ million over 12 months. ${ }^{10}$

Health care system transformation will occur under this strategy, as a result of intentional learning ${ }^{2}$ with implications for policy. Super-utilizers are "superdetectors," helping to clearly identify system inefficiencies and their link to low-value care. A common observation among SU programs is the detrimental impact of social determinants on health. ${ }^{11,12}$ The "medicalization" of social determinants directs resources to higher cost medical care rather than addressing social needs, resulting in recurring high cost, low effectiveness care. In a striking example in Trenton, New Jersey, a super-utilizer visited the hospital 450 times in 1 year. ${ }^{13}$ Unstable housing was noted as a major contributor to her utilization. After securing stable housing, her hospital visits dropped the following year to $12 .{ }^{13}$ 
Can developing delivery models for a segment of the population equate to system transformation? Yes, when tied to alternative payment methods; real-time utilization data; easily accessible, state supported health information exchange ${ }^{10}$; and resource allocation to address social determinants. For scalability, the strategies' processes must be data-informed and deliver on outcomes. As health care expenditures overwhelm federal and state budgets and force difficult decisions regarding coverage and services, ${ }_{1}^{14,15}$ the SU strategy is the meeting point for the value mandates to improve care and reduce expenditures. Focusing on superutilizers positions us to help patients who often aren't getting the kind of care they need while creating the greatest short-term return on investment with cost savings to the system. Fortunately, the Affordable Care Act is serving as a vector to scale SU strategy through State Innovation Model grants. ${ }^{16}$

Improving care delivery for super-utilizers will transform overall health care delivery because the strategy doesn't patch the holes in the system, but rather provides a framework for changing the system. By using data to highlight the discrepancy between health expenditures and outcomes, resource allocation is a powerful lever to move toward a high value health care system. The multifaceted approach of this strategy, rooted in data, clinical redesign, and stakeholder engagement, is equal to the task of health care system transformation.

To read or post commentaries in response to this article, see it online at http://www.annfammed.org/content/13/1/6.

Key words: super-utilizer; care coordination; delivery of healthcare; health expenditures; social determinants of health; resource allocation

Submitted November 25, 2014; submitted, revised November 25, 2014; accepted November 26, 2014.

Acknowledgments: I thank Barry Jacobs and Wendell Kellum for their assistance in early editions of this piece.

\section{References}

1. Miller A, Cunningham M, Ali N. Bending the cost curve and improving quality of care in America's poorest city. Popul Health Manag. 2013;16(Suppl 1):S17-S19.

2. Bodenheimer T. Center for Health Care Strategies, Inc. Strategies to reduce costs and improve care for high-utilizing medicaid patients: reflections on pioneering programs. Policy brief. http:// www.anthem.com/provider/noapplication/f1/s0/t0/pw_e211389. pdf?refer= provider. Published Oct 2013.
3. Stanton MW, Rutherford MK; Agency for Healthcare Research and Quality. The high concentration of US health care expenditures. http://meps.ahrq.gov/mepsweb/data_files/publications/ra19/ra19. pdf. Published Jun 2006.

4. Porter ME, Lee TH. The strategy that will fix health care. Harv Bus Rev. 2013;91(10):50-70.

5. Gawande A. The hot spotters. The New Yorker. 2011;86(45):40-51.

6. Gross K, Brenner JC, Truchil A, Post EM, Riley AH. Building a citywide, all-payer, hospital claims database to improve health care delivery in a low-income, urban community. Popul Health Manag. 2013;16(Suppl 1):S20-S25.

7. Hasselman, Dianne. Robert Wood Johnson Foundation. Center for Health Care Strategies, Inc. Super-utilizer summit: common themes from innovative complex care management programs. http://www. rwjf.org/content/dam/farm/reports/reports/2013/rwjf407990. Published Oct 2013.

8. Coburn KD, Marcantonio S, Lazansky R, Keller M, Davis N. Effect of a community-based nursing intervention on mortality in chronically ill older adults: a randomized controlled trial. PLoS Med. 2012;9(7):e1001265.

9. Schore J, Peikes D, Peterson G, Gerolamo A, Brown R. Fourth report to Congress on the evaluation of the Medicare Coordinated Care Demonstration. Prepared by Mathematica Policy Research for the US department of Health and Human Services. https://www.cms. gov/reports/downloads/Schore_Fourth_Eval_MCCD_March_2011. pdf. Published Mar 2011.

10. Warning W, et al. South Central Pennsylvania High Utilizer Collaborative. Working with the super-utilizer population: the experience and recommendations of five Pennsylvania programs. http://www. aligning4healthpa.org/pdf/High_Utilizer_report.pdf. Published Jun 2014.

11. Brennan Ramirez LK, Baker EA, Metzler M. US Department of Health and Human Services, Centers for Disease Control and Prevention. Promoting Health Equity: A Resource to Help Communities Address Social Determinants of Health. http://www.cdc.gov/nccdphp/ $\mathrm{dch} /$ programs/healthycommunitiesprogram/tools/pdf/SDOHworkbook.pdf. Published 2008.

12. Bradley EH, Elkins BR, Herrin J, Elbel B. Health and social services expenditures: associations with health outcomes. BMJ Qual Saf. 2011;20(10):826-31.

13. Buck E, Brenner J. There's no place like home in health care: housing the homeless is key to controlling costs. Philly.com. June 16, 2014, http://www. philly.com/philly/blogs/fieldclinic/Theres-NoPlace-Like-Home-in-Health-Care-Housing-the-Homeless-is-Key-toControlling-Costs.html?c=r. Published Jun 16, 2014.

14. Centers for Medicare and Medicaid Services. National Health Expenditure Projections 2012-2022. http://www.cms.gov/ResearchStatistics-Data-and-Systems/Statistics-Trends-and-Reports/NationalHealthExpendData/downloads/proj2012.pdf. Published 2014.

15. The National Association of State Budget Officers. Healthcare and Medicaid. http://www.nasbo.org/budget-topics/healthcaremedicaid. Published Nov 2014.

16. Silow-Carroll S, Lamphere J. State innovation models: early experiences and challenges of an initiative to advance broad health system reform. http://www.commonwealthfund.org/publications/issuebriefs/2013/sep/state-innovation-models. Published Sep 25, 2013. 